\title{
Modelling potential climate change impacts on sediment yield in the Tsitsa River catchment, South Africa
}

\author{
Simone Norah Theron ${ }^{1,2}$ (D), Harold Louw Weepener ${ }^{1}$, Jacobus Johannes Le Roux ${ }^{3}$ and Christina Johanna Engelbrecht ${ }^{1,2}$ \\ 'Institute for Soil, Climate \& Water, Agricultural Research Council, 600 Belvedere Street, Arcadia, Pretoria, 0083, South Africa \\ 2Department of Geography, Geo-Informatics and Meteorology, University of Pretoria, Lynnwood Road, Hatfield, Pretoria, 0002, South Africa \\ ${ }^{3}$ Department of Geography, University of the Free State, 205 Nelson Mandela Dr, Park West, Bloemfontein, 9300, South Africa \\ *Current affiliation: Institute for Soil, Climate \& Water, Agricultural Research Council, Infruitec Campus, Helshoogte Road, Stellenbosch, \\ 7500, South Africa
}

The effects of climate change on water resources could be numerous and widespread, affecting water quality and water security across the globe. Variations in rainfall erosivity and temporal patterns, along with changes in biomass and land use, are some of the impacts climate change is projected to have on soil erosion. Sedimentation of watercourses and reservoirs, especially in water-stressed regions such as sub-Saharan Africa, may hamper climate change resilience. Modelling sediment yield under various climate change scenarios is vital to develop mitigation strategies which offset the negative effects of erosion and ensure infrastructure remains sustainable under future climate change. This study investigated the relative change in sediment yield with projected climate change using the Soil and Water Assessment Tool (SWAT) for a rural catchment in South Africa for the period 2015-2100. Data from six downscaled Coupled Global Climate Models (CGCM) were divided into three shorter time periods, namely, 2015-2034, 2045-2064 and 2081-2100. Results were then compared with a control scenario using observed data for the period 2002-2017. The results show that, if left unmanaged, climate change will likely lead to greater sediment yield, of up to $10 \%$ more per annum. Peak sediment yield will also increase almost three-fold throughout the century. The study shows that projected climate change will have multiple negative effects on soil erosion and emphasised the need for changes in climate to be considered when embarking on water resource developments.

\section{INTRODUCTION}

South Africa has scarce water resources and already exploits approximately $98 \%$ of its available water supply (Hedden and Cilliers 2014). Climate change and population growth are placing further demands on the available water resources (Florke, et al., 2018; Le Roux, 2018; Rawlins, 2019). This makes the construction and management of water resource infrastructure paramount for economic and social development (SIWI, 2005; DWS, n.d.). South Africa, in particular, has stressed the importance of water infrastructure to reduce climate vulnerability through reports such as the National Adaptation Strategy (NAS) and the Long-Term Adaptation Scenario (LTAS) for Water (DEA, 2013; 2016; DWS, n.d.). The recent 2015-2018 Cape Town drought is a stark warning, however, of the effects of changing climate on water resources, with anthropogenic climate change having tripled the likelihood of such a drought occurring (Otto et al., 2018).

Concerns over water security and climate change tend to focus on water availability and the hydrological cycle and fewer studies are concerned with the effects of climate change on water quality, particularly from a sedimentation perspective. Potential impacts of climate change on water security include decreased quality and quantity of available water and increased inter-annual variability (Kusangaya et al., 2014; Seneviratne et al., 2012; Tabari, 2020); increase in drought intensity and return period (Davis-Reddy and Vincent, 2017; Tabari, 2020); and increased evapotranspiration (Wu et al., 2009). Yet, climate change is also projected to affect runoff and erosion rates (Nearing et al., 2004, Mullan et al., 2012, Mullan 2013; Simonneaux et al., 2015). Direct impacts of climate change on soil erosion include variations in rainfall erosivity, temporal changes in rainfall, changes in soil moisture content, and changes in wind erosion (Mullan et al., 2012). Indirectly, changes in temperature, solar radiation and atmospheric $\mathrm{CO}_{2}$ concentrations will impact plant biomass production, infiltration rates, soil moisture, land use and crop management, which in turn will affect runoff and soil erosion (Nearing et al., 2004).

In 2014 the South African Department of Water and Sanitation put forward proposals for a dam on the Tsitsa River, a tributary of the Mzimvubu River (Fig. 1), as a potential site for a water resource development (DWS, 2014). The Mzimvubu River remains South Africa's largest river without a dam (Le Roux et al., 2015; Le Roux, 2018; Pretorius, 2017). It is envisioned that a dam will spark economic growth while also helping to secure current and future water resources (DWS, 2014). Earlier studies conducted in the Tsitsa and larger Mzimvubu show that both catchments are prone to extensive and severe soil erosion, particularly gully erosion (Van Tol et al., 2014; Le Roux, 2018; Pretorius, 2017). This will have serious detrimental effects on the lifespan and productivity of any water resource developments (Godwin, et al., 2011; Alemaw, et al., 2013). The potential for increased sediment yield, and consequently increased siltation, poses several threats to water resource developments, including

\section{CORRESPONDENCE}

Simone N Theron

\section{EMAIL}

PretoriusS@arc.agric.za

\section{DATES}

Received: 17 March 2020

Accepted: 20 January 2021

\section{KEYWORDS}

soil erosion

climate change

hydrological modelling

SWAT

sediment yield

erosivity

sedimentation

\section{COPYRIGHT}

(C) The Author(s)

Published under a Creative Commons Attribution 4.0 International Licence (CC BY 4.0) 
reduced reservoir storage capacity, and increased pressure on the dam wall, and may affect flood attenuation (Mama and Okafor, 2011; Schellenberg et al., 2017).

Dams are envisioned to last several decades, and with projected climate change it is becoming increasingly important to understand the effects that the changing climate will have on the future soil erosion scenarios in priority catchments. Although several studies have been conducted on the effects of climate change on soil erosion across the globe, there is a noticeable lack of such research in the developing regions of sub-Saharan Africa (Msadala et al., 2010; Manase, 2010; Kusangaya et al., 2014). Hydrological modelling with the use of the Soil and Water Assessment Tool (SWAT) has been successfully applied to many regions in Africa (see, for example, Ndomba and Van Griensven (2011) and Chaplot (2014)). Several studies have used SWAT for climate change and hydrology analysis in Africa, for example, Setegn et al. (2011) used SWAT to determine climate change effects on the hydrology of Lake Tana, Ethiopia, and Van Griensven et al. (2012) reviewed climate models and uncertainty in the Nile Basin. Overall, research on the effects on climate change and sedimentation in Africa remains limited, particularly given the variability of soils, climates, and land use across Africa. SWAT has the potential to model many of the direct and indirect impacts of climate change on catchments, such as changes in rainfall, vegetation cover, soil moisture, land management and land abandonment. Furthermore, SWAT is routinely coupled with geographical information systems (GIS), which offer unprecedented flexibility in the representation and organisation of spatial data (Le Roux et al., 2013).

Considering this catchment has been earmarked for potential water resource developments, our study set out to conduct a preliminary investigation into the potential effects of climate change on soil erosion. The aim is to model the effects of the sediment yield contribution from sheet-rill erosion under projected climate change using the hydrological model SWAT, which was met through the following objectives: (i) to model the sediment yield and rainfall erosivity in the upper Tsitsa catchment using a 15-year control period from observed data (2002-2017), and (ii) to determine the sediment yield and rainfall erosivity in the upper Tsitsa Catchment using projected climate data for the period 2015-2100, broken down into three time periods, namely,
2015-2034 (short-term), 2045-2064 (mid-term) and 2081-2100 (long-term). Since SWAT does not account for gullies and gully erosion is prevalent in the catchment it is acknowledged that erosion rates will be underestimated by this approach.

\section{STUDY AREA}

Our study site is the upper Tsitsa catchment (approximately 2000 $\mathrm{km}^{2}$ ) which is situated in the Eastern Cape Province of South Africa (Fig. 1). The Tsitsa River, which drains the upper Tsitsa catchment, rises on the Drakensberg Escarpment (max elevation $2700 \mathrm{~m}$ asl) and falls to an elevation of roughly $900 \mathrm{~m}$ asl at its confluence with the Gqukunqa River near the village of Siqungqweni (Fig. 1). The catchment lies in the summer rainfall region (September-April) receiving approximately $850 \mathrm{~mm}$ of rainfall per annum (AgroMeteorology Staff, 1984-2020). Temperatures are warm, with daily mean summer temperatures of $12^{\circ} \mathrm{C}$ to $26^{\circ} \mathrm{C}$ and daily mean winter temperatures of $4^{\circ} \mathrm{C}$ to $18^{\circ} \mathrm{C}$.

Land cover in the catchment is classified as being predominantly natural vegetation $(72 \%)$, which is composed of grassland (90\%), thicket (6.9\%), forest (3\%) and shrubland (0.1\%) (DEA, 2015). Cultivated commercial and subsistence agriculture make up $15 \%$ of the catchment; however, livestock grazing also occurs extensively in the grassland areas. Plantations, towns, forests, and water bodies make up the remaining $13 \%$ of land use in the catchment (DEA, 2015; Le Roux et al., 2015). Commercial farms in the region are mainly cattle for dairy and meat. The lower reaches of the upper Tsitsa Catchment fall within the former Transkei homeland and, although the homelands policy was abolished in 1994, it remains one of the poorest and least developed regions of South Africa, with the majority of the population relying on subsistence farming and social grants for their livelihood (Pretorius, 2017).

Soils have been described as highly erosive and dispersive; these properties are caused by the presence of duplex soils (Van Tol et al., 2014; Le Roux, 2018). The majority of the soils are of a clayey or loamy or a clayey loam texture with some sandy loam and sandy clay texture (Le Roux et al., 2015). Soil depths range from $10 \mathrm{~cm}$ to $200 \mathrm{~cm}$, with the shallowest soils $(<30 \mathrm{~cm})$ occurring on the rocky and steeply sloped areas. Deeper soils $(>50 \mathrm{~cm})$ are mainly located on flatter terrain found on the lower foot slopes and valley bottoms (Le Roux et al., 2015; Pretorius, 2017).

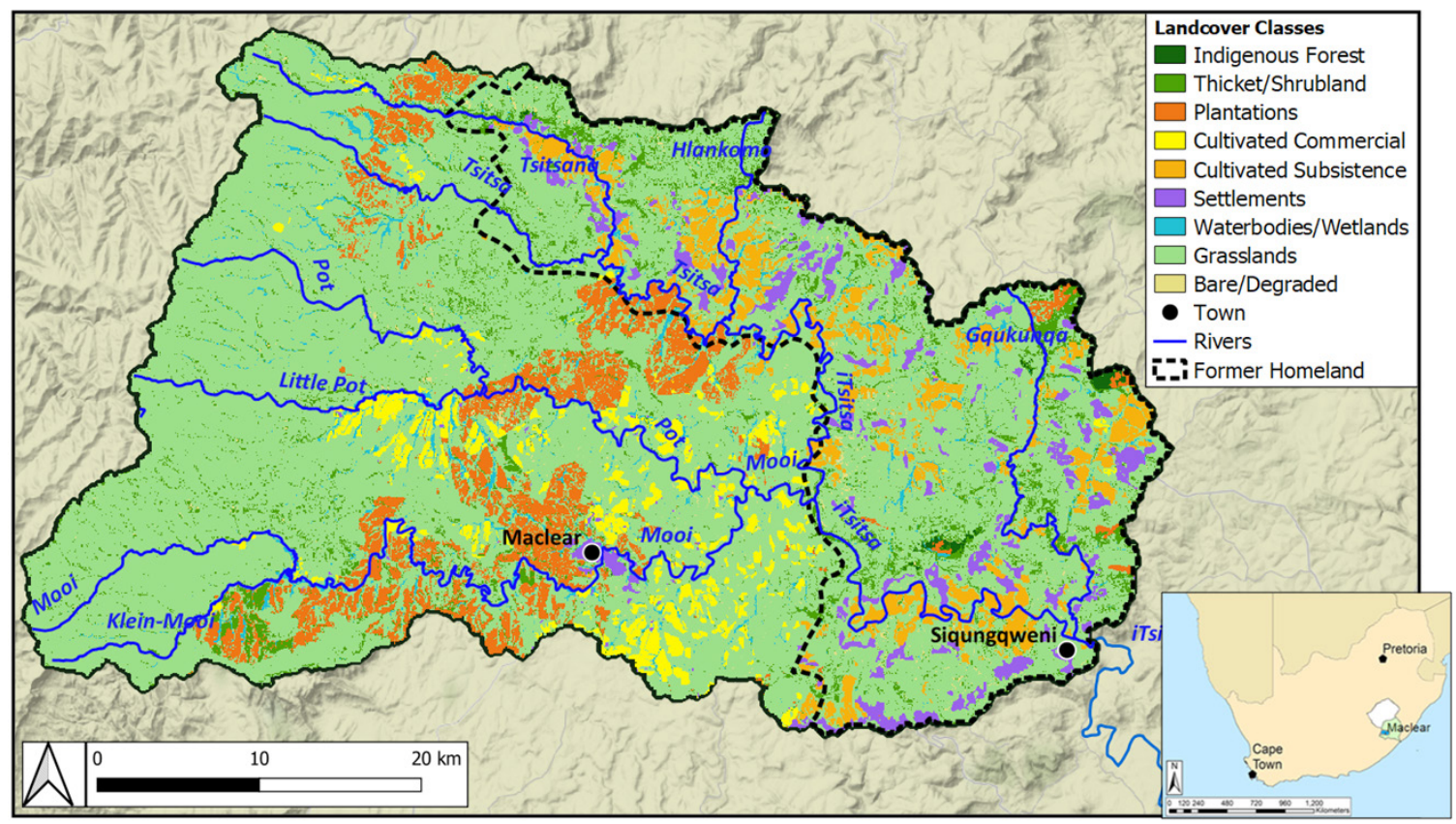

Figure 1. Map of the upper Tsitsa catchment showing the landcover classifications as well as the boundary of the former homeland 


\section{MATERIALS AND METHODS}

Effects of climate change on soil erosion and sedimentation in the catchment were assessed using changes in rainfall (both observed and projected), along with two proxy measures of erosion and sedimentation, namely sediment yield (estimated in SWAT) and rainfall erosivity (calculated using the modified Fournier Index). Simulation of the relative change in sediment yield with projected climate change was conducted using the SWAT 2012.10_2.19 version in ArcMap 10.2.2. SWAT is an empirically based, continuous time, semi-distributed, catchment-scale model that accounts for most connectivity aspects. SWAT accounts for the connectivity of sediment generated on hillslopes and how it sinks to a channel by overland and subsurface flow (Le Roux et al., 2013). SWAT was selected primarily because it has been applied successfully for various large catchment (10-10 $\left.000 \mathrm{~km}^{2}\right)$ modelling studies across the world, including in Africa, and had previously been used to estimate sediment yield for the Tsitsa River catchment (Le Roux et al., 2015; Wahren et al., 2016). SWAT considers water and sediment fluxes in large catchments with varying climatic conditions, soil properties and land use combinations.

The modified Fournier Index $\left(\mathrm{FI}_{\mathrm{m}}\right)$ (Eq. 1) was used to calculate rainfall erosivity, which is expressed as a dimensionless index value. $\mathrm{FI}_{\mathrm{m}}$ is a methodology frequently used to estimate rainfall erosivity (Sauerborn, et al., 1999). Studies have shown that the $\mathrm{FI}_{\mathrm{m}}$ approach is appropriate to gauge rainfall aggressiveness and is correlated to other climatic variables, which are contributing factors in erosion events (Costea, 2012). The erosivity classes used to interpret the $\mathrm{FI}_{\mathrm{m}}$ results are shown in Table 1 (Yahaya et al., 2016). $\mathrm{FI}_{\mathrm{m}}$ was calculated with monthly values for each month of the year and then averaged for each year. The $\mathrm{FI}_{\mathrm{m}}$ was calculated using both observed data and projected climate data for each period.

$$
\text { Modified F } 1=\frac{\sum(p 1, p 2, \ldots p 12)^{2}}{p}
$$

where: $p=$ average monthly rainfall; $P=$ average annual rainfall

\section{Climate change input data}

CGCMs are currently the most suitable models for projecting future climate change scenarios. Temperature and rainfall projections of climate change have been successfully used in a variety of hydrological models, including SWAT, to determine the effects of changing climate on various environmental processes such as soil erosion (Mullan et al., 2012).

Regional projections of climate change were used to obtain the projected changes in sediment yield at the catchment scale. Six different Coupled Global Climate Models (CGCM) or ensemble member (Table 2) projections for the A2 Special Report on Emissions Scenarios, 2000 (SRES) were used (Nakicenovic et al., 2000). These were dynamically downscaled to high resolution over South Africa for the period 1961 to 2100 by Engelbrecht et al. (2011). The downscaling made use of the regional Conformal-Cubic Atmospheric Model. More detail on these ensemble members can be found in Malherbe et al. (2013). The A2 emissions scenario was used in this study as it was the scenario used by Englebrecht et al. (2011) when downscaling the data over South Africa. Since then, various other RCPs have been developed (Van Vuuren et al., 2011). The projections used in this study are the same projections used in the study by Engelbrecht and Engelbrecht (2016) and a detailed description of the downscaling procedure can be found in Engelbrecht et al. (2011). The CGCMs were bias-corrected by Engelbrecht et al. (2011) using sea-surface temperature biases, which were derived by comparing the simulated and observed present-day climatology of sea-surface temperatures for 1979-1999 for each month of the year. The same monthly bias corrections were applied for the duration of the simulations
Table 1. The Modified Fournier Index value and severity of erosivity according to Yahaya et al., (2016)

\begin{tabular}{lc}
\hline Index value & Erosivity \\
\hline $0-60$ & Very low \\
$60-90$ & Low \\
$90-120$ & Moderate \\
$120-160$ & Severe \\
$>160$ & Very severe \\
\hline
\end{tabular}

Table 2. The six CGCMs on which the Council for Scientific and Industrial Research (CSIR) performed dynamical downscalings in order to develop an ensemble of high-resolution $(50 \mathrm{~km} \times 50 \mathrm{~km}$ horizontal resolution) projections of the future climate for southern Africa

\begin{tabular}{ll}
\hline CGCM & \multicolumn{1}{c}{ Source } \\
\hline GFDL-CM 2.0 & The version 2.0 CGCM of the Geophysical \\
& $\begin{array}{l}\text { Fluid Dynamics Laboratory (GFDL) of } \\
\text { the National Oceanic and Atmospheric } \\
\text { Administration (NOAA) in the United States }\end{array}$ \\
& The version 2.1 CGCM from GFDL
\end{tabular}

ECHAM5/MPI-OM ECHAM5/MPI-Ocean Model from ECHAM5/ MPI-O Min Germany

UKMO-HadCM 3 The Met Office Third Hadley Centre Coupled Ocean Atmosphere CGCM - United Kingdom

MIROC 3.2-medres Model for Interdisciplinary Research on Climate 3.2 medium resolution version, of the Japanese Agency for Marine-Earth Science and Technology

CSIRO MK 3.5 The version 3.5 CGCM of the Commonwealth Scientific and Industrial Research Organisation in Australia

(Engelbrecht et al., 2011). A major advantage in using CGCMs is that they provide a daily time resolution of future climate, which removes the problem of assigning precipitation change between number of wet days and the amount of precipitation on a wet day (Mullan et al., 2012).

For the purpose of this study, the model grid point closest to the geographical location of the study site $(28.248898,-30.752091)$ was used to extract all the relevant simulated climate parameters (rainfall, minimum and maximum temperature) on a daily time scale. In this study, the downscaled projections of climate change of the six ensemble members were first divided into three nonoverlapping shorter time periods with a 5-year warm-up period (indicated in the square brackets), namely, 2015[2009]-2034 (short-term), 2045[2039]-2064 (mid-term) and 2081[2075]2100 (long-term) before been run in SWAT.

\section{SWAT model setup}

Erosion caused by rainfall and runoff is computed with the Modified Universal Soil Loss Equation (MUSLE). The algorithms and equations used are described in Arnold et al. (2012). The MUSLE predicts sediment yield by grouping the influences on the erosion process into five causal factors (also known as USLE factors), including rainfall erosivity in $\mathrm{MJ} \cdot \mathrm{mm} /(\mathrm{ha} \cdot \mathrm{hr} \cdot \mathrm{yr})$, soil erodibility in $\mathrm{t} \cdot \mathrm{ha} \cdot \mathrm{hr} /(\mathrm{ha} \cdot \mathrm{MJ} \cdot \mathrm{mm})$, hillslope length and gradient, vegetation cover factor, and supporting practices. The MUSLE replaces the USLE rainfall energy factor with a runoff factor, eliminating the need for delivery ratios, and allows the equation to be applied to individual storm events (Fig. 2). Daily rainfall values were obtained from the Agricultural Research Council-Institute for Soil, Climate and Water (Agro-meterology Staff, 1987-2020) for the observed, control period (2002-2017) from the weather station (Station ID 30149) 


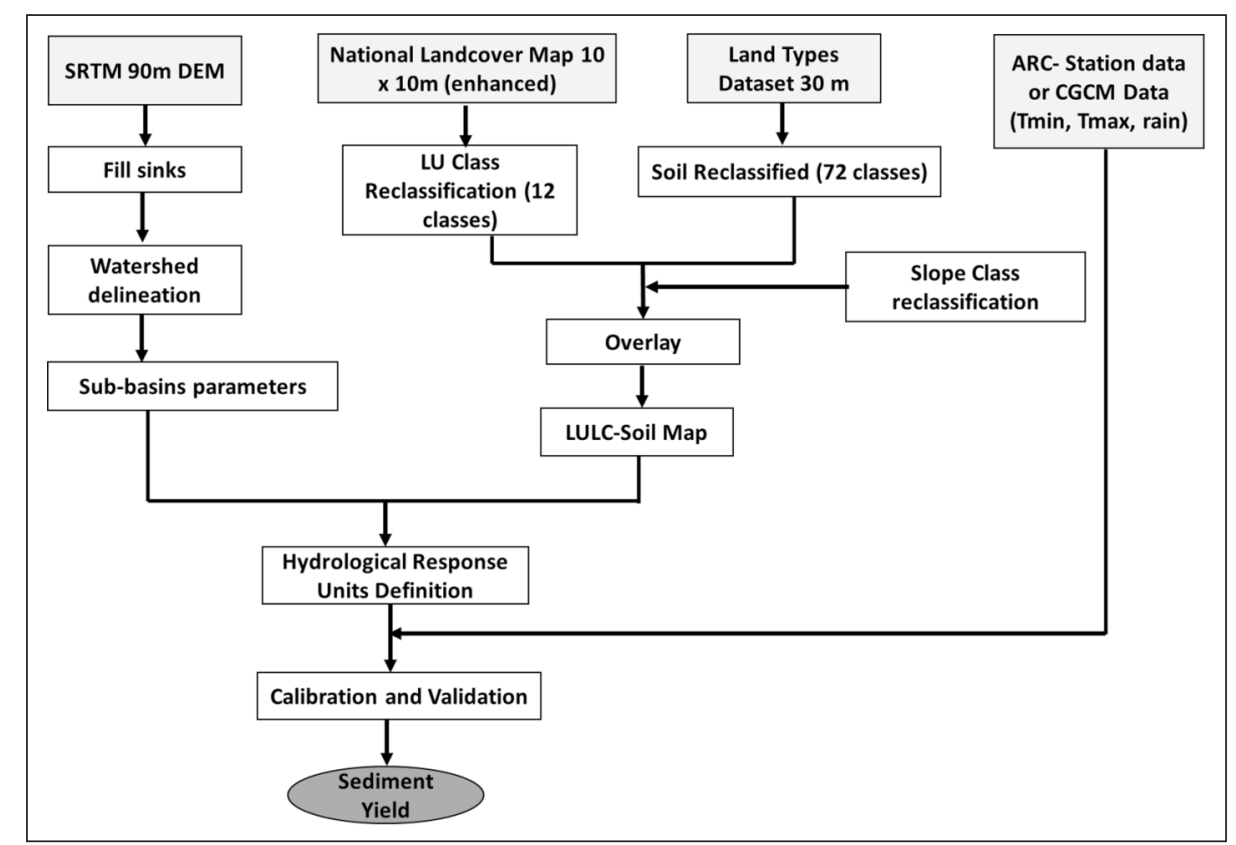

Figure 2. Workflow chart of the SWAT model with the input data used in the study

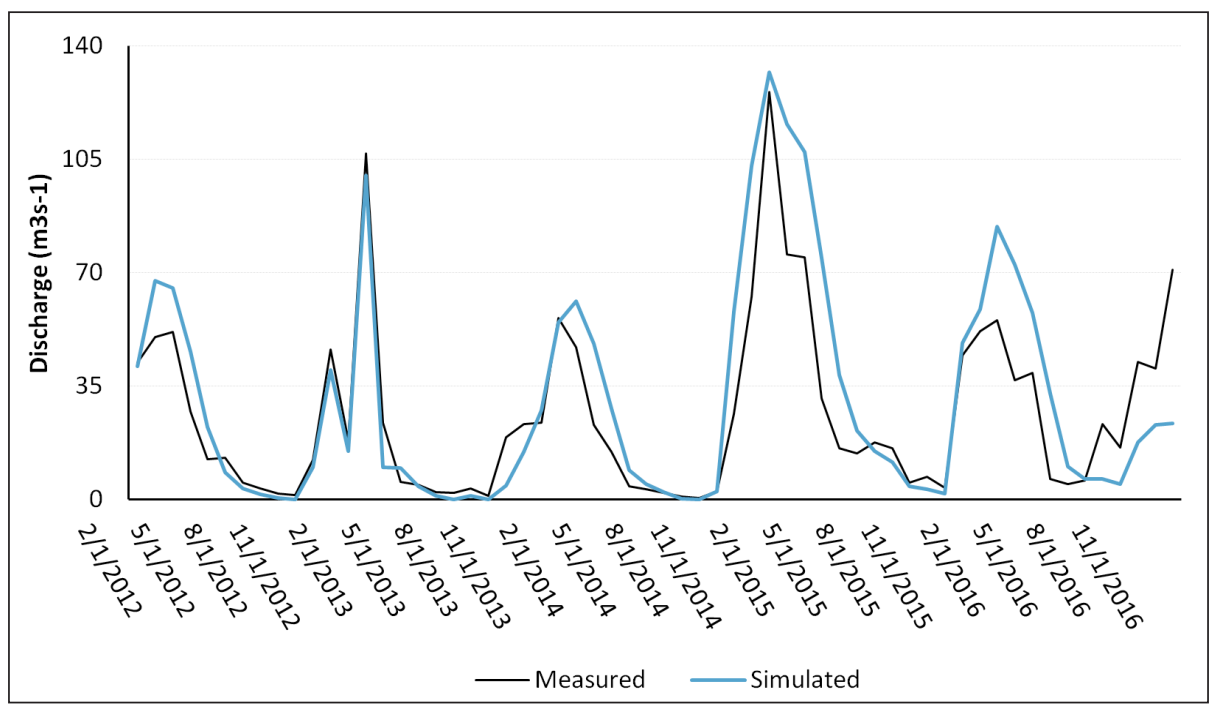

Figure 3. Calibrated SWAT discharge results compared with measured discharge at the gauging station (T3H006) nearest to the proposed dam

located closest to but not in the catchment $(-31.352659 \mathrm{~S}$, 28.047380 E). The National Land Cover map with a 10 x $10 \mathrm{~m}$ pixel size (improved by Le Roux et al. 2015) was used as the land cover input and the Land Type data with a $30 \mathrm{~m}$ resolution (prepared by the Land Type Survey Staff (1976-2006)) was used as the soil input. The hydrologically improved Shuttle Radar Topography MissionDigital Elevation Model (SRTM-DEM) with a resolution of $90 \mathrm{~m}$ created by Weepener et al. (2012) was used as the input digital elevation model (DEM). Although $90 \mathrm{~m}$ is too coarse to represent small topographic features, it was considered sufficient for the automated routines run in SWAT for this study (e.g., dividing large catchments into smaller sub-catchments and calculating the average slope for each from a DEM). Twenty-four subcatchments represented all the major tributaries of the main river and ensured that flow monitoring points were spatially overlain with sub-catchment outlet points. Each of the 24 sub-catchments consists of a channel with unique geometric properties, including slope gradient, length, and width. These are portions of a subcatchment that possess unique land use and soil attributes. Similar to Bouraoui et al. (2005), the parametrisation was done to keep the number of HRUs down to a reasonable number (47), while still considering the full diversity and sensitivity of land cover and soil combinations. The study aimed at integrating all land cover units that significantly affect the sediment yield of a catchment, whether large or small in spatial extent.

Validation and calibration of SWAT was conducted previously by Le Roux et al. (2015), using flow measurements from the downstream station (coded T3H006) and nearest to the future dam, retrieved from the Department of Water and Sanitation (Fig. 3). A major limitation to the use of continuous time models in developing countries is the lack of recorded flow and sediment data needed for validation and calibration. In this study, due to the absence of data on sediment loads, the model calibration concentrated on the hydrological component by adjusting model parameters in a manner similar to Tibebe and Bewket (2011) by modifying the curve number and base-flow coefficients (Le Roux et al., 2015). Model performance was enhanced by adjusting/ optimising the input parameters to improve model performance resulting in $a>r^{2}$ and $E$ (Nash and Sutcliffe, 1970). A per cent deviation method of Martinec and Rango (1989) was used as a measure of goodness-of-fit between simulated and measured discharge. The goodness of fit expressed by $r^{2}$ was $88 \%$ and $E$ was $75 \%$, whereas discharge was over-predicted by $14 \%$. 


\section{RESULTS}

To determine the accuracy of the projected rainfall data, each ensemble member was compared with the control data over the period 2002-2017 (Fig. 4). All the downscaled ensemble members' projections underestimated, by approximately $10 \%$, the amount of rainfall during the control period. This underestimation of rainfall is noteworthy and should be considered when interpreting the derived sediment yield and erosivity for the modelled period 2015-2100. Variations between the models were low, with only a $5 \%$ variation between the highest (UKMO-HadCM3) and lowest (ECHAM5/MPI-OM) rainfall projection.

Figure 5 illustrates the rainfall event type per ensemble member derived from projected rainfall. In all the downscaled model projections, lighter $(<5 \mathrm{~mm})$ rainfall events were over-estimated for the control period 2002-2017, while the more intense rainfall events, $10 \mathrm{~mm}$ and $15 \mathrm{~mm}$, were under-estimated, by 70 and $95 \%$, respectively. In addition, Figure 4 shows the projected frequency of annual occurrences of $5 \mathrm{~mm}, 10 \mathrm{~mm}$ and $15 \mathrm{~mm}$ rainfall events for each of the six GCM projections for each time period. All the projections indicate an increase in $15 \mathrm{~mm}$ events throughout the century and most of the projections show an increase in the $10 \mathrm{~mm}$ events. This suggests that the number of extreme rainfall events is projected to increase throughout the century up until 2100. Even though the ensemble members under-estimated larger rainfall events, the models predict a relative increase in extreme events, between 2 - and 10 -fold up to 2100 .

Figure 6 indicates the range of annual rainfall for the ensemble members over the period 2015-2100. The maximum annual rainfall is just over $1000 \mathrm{~mm}$ while the minimum is just less than $400 \mathrm{~mm}$. There is a narrowing in the range between the maximum and minimum projected rainfall during the 2030-2055 period (indicated by the box), which falls in the mid-term time period. The reduced range also tends towards less rainfall. The long-term period (2081-2100) shows the greatest range and disagreement between the models in predicted rainfall and, consequently, both the highest and lowest rainfall predictions occur in this time period.

Figure 7 shows the rainfall, erosivity and sediment yield as an average of the six ensemble members for each of the time periods. Each erosion index predicts a large increase from the start to the end of the century. The increase is not uniform and there is a noticeable decrease in the mid-term (2045-2064), which may be partially explained by the lower range in rainfall as well as the lower rainfall observed in Fig. 6 in this period. Higher sediment yield, rainfall and erosivity for the short and long term are caused by extremities in rainfall during those periods, which can also be observed in Fig. 5. Between the short- and long-term, sediment yield increases by $14 \%$, erosivity by $2.5 \%$ and rainfall by $5.5 \%$. Erosivity can be described as low to moderate $\left(\mathrm{FI}_{\mathrm{m}}>60\right)$ in all three time periods.

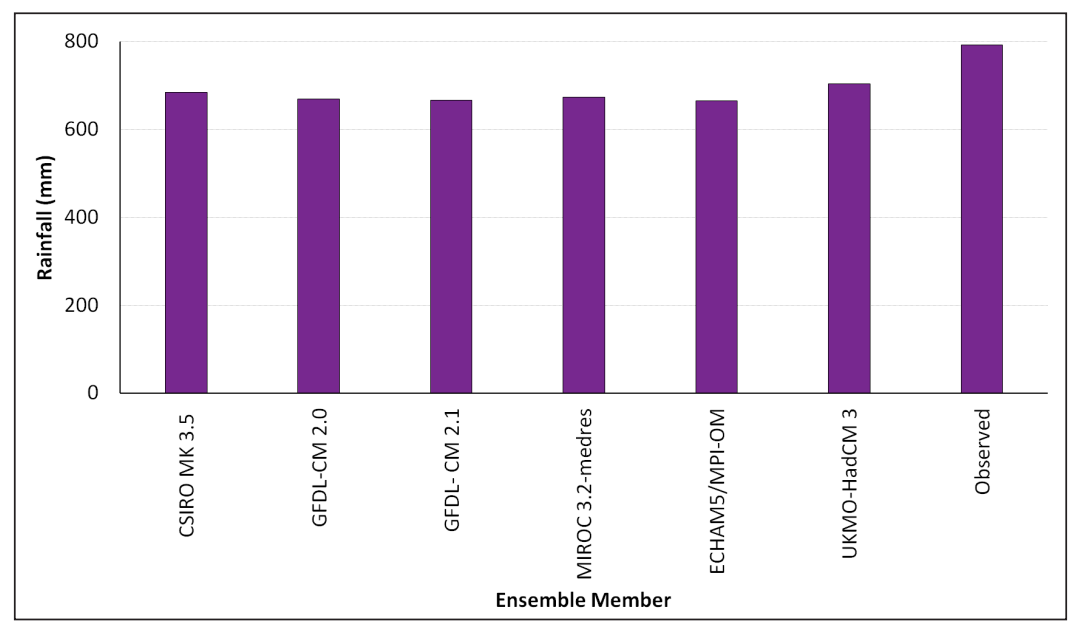

Figure 4. The mean annual rainfall projected by each ensemble member, along with the observed mean annual rainfall for the period 2002-2017 in the upper Tsitsa catchment

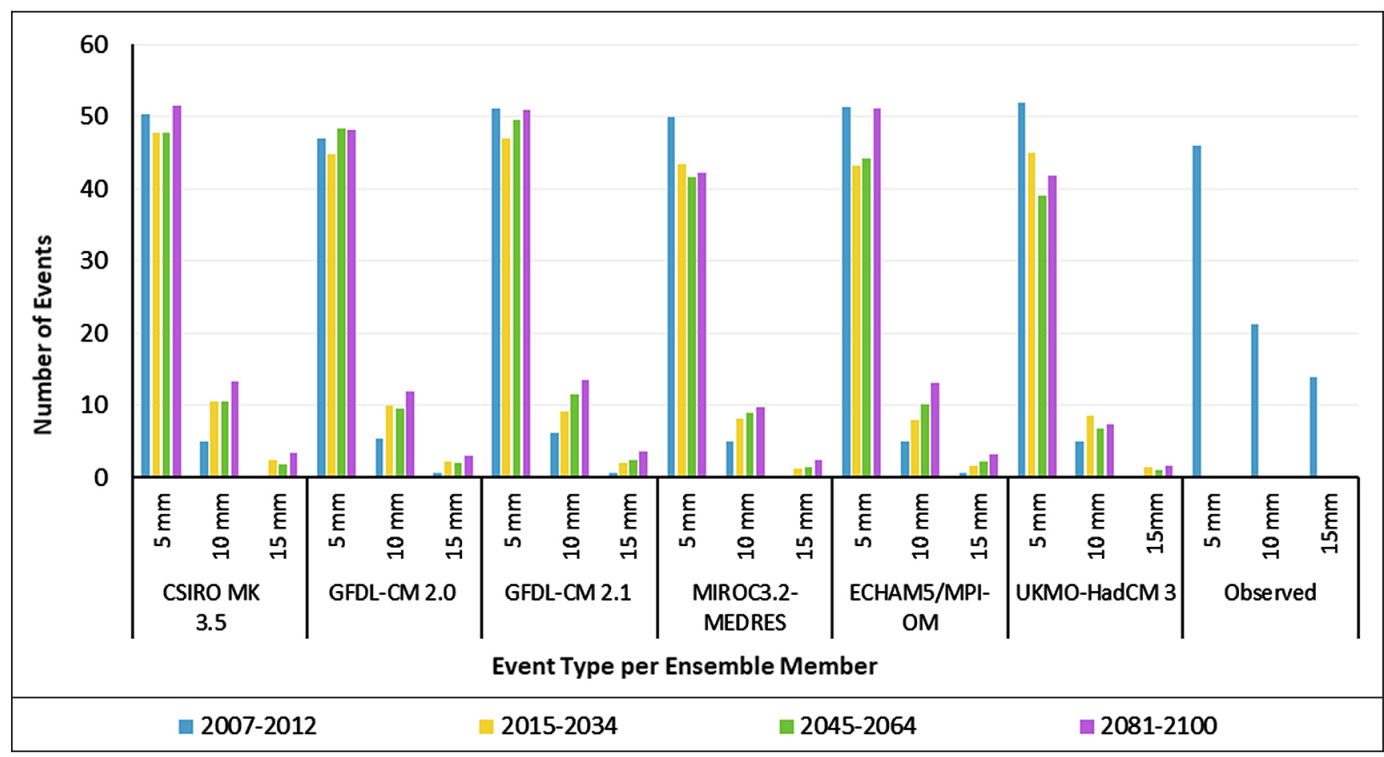

Figure 5. The number of $5 \mathrm{~mm}$ (light), $10 \mathrm{~mm}$ (medium) and $15 \mathrm{~mm}$ (heavy) rainfall events in the upper Tsitsa catchment, Eastern Cape, South Africa, for the time periods 2015-2035, 2045-2064, 2081-2100 for each ensemble member, along with the control data (observed) 


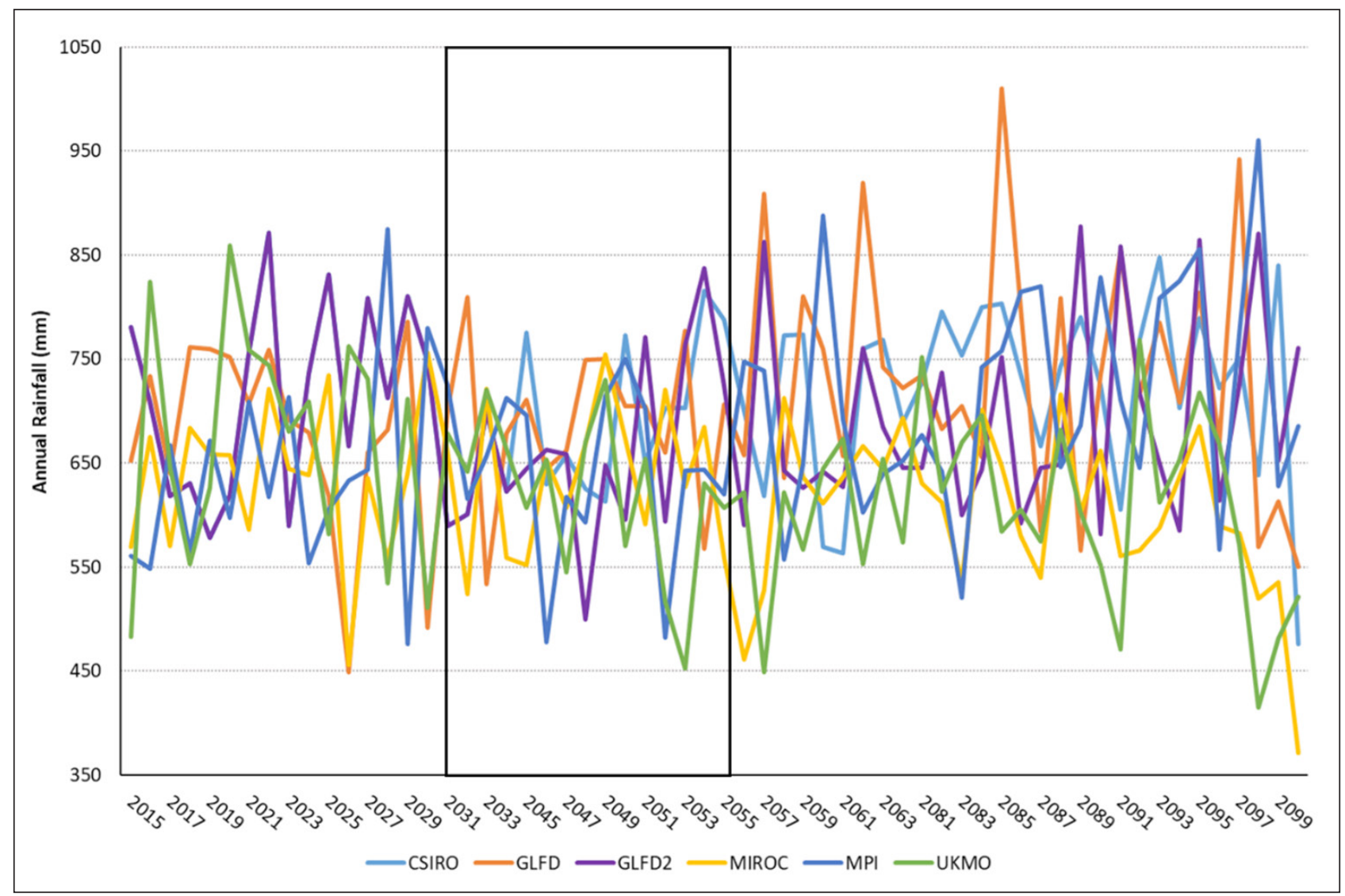

Figure 6. The range of mean annual rainfall in the upper Tsitsa catchment, Eastern Cape, South Africa, for the six ensemble members over the period 2015-2100

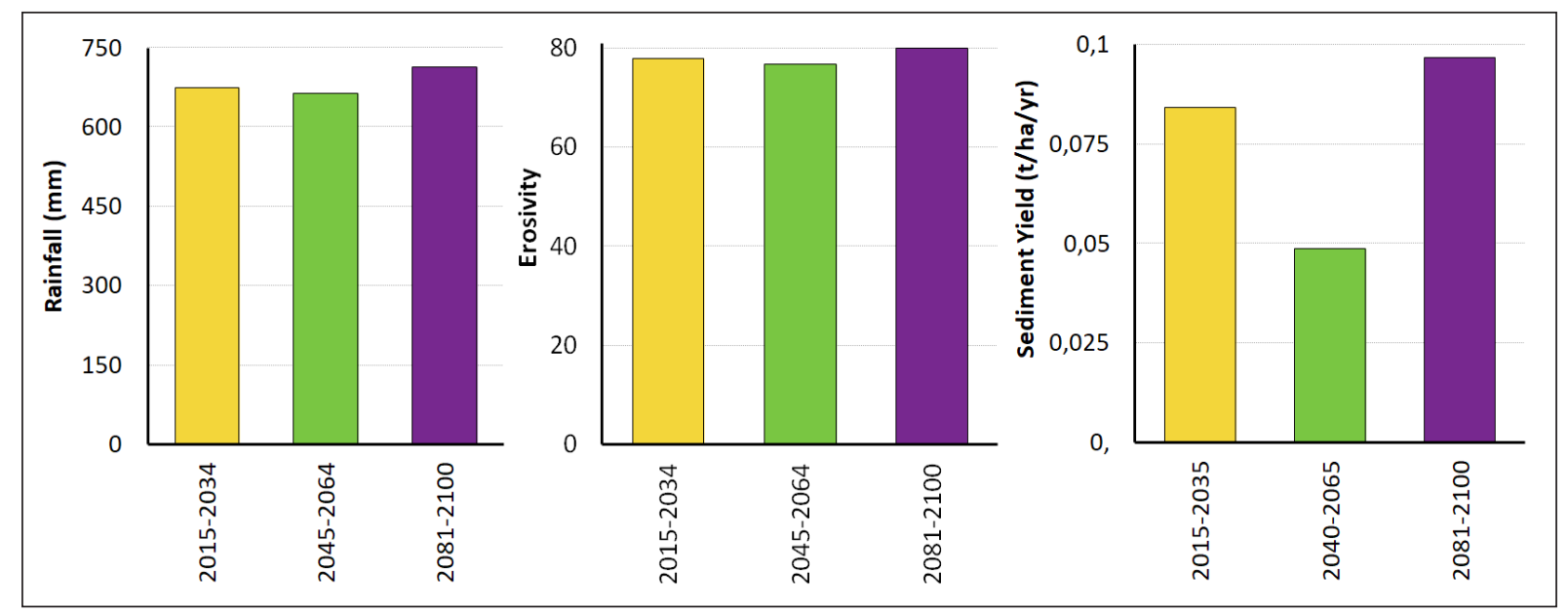

Figure 7. Mean of the six ensemble member predictions averaged for each period (2015-2034, 2045-2064, 2081-2100) in the upper Tsitsa catchment, Eastern Cape, South Africa. From left to right: mean of the annual rainfall; mean annual Modified Fournier Index; mean of the annual sediment yield predicted by SWAT

Table 3 shows the range of possible sheet and rill erosion-derived sediment yield estimates as well as the variability between the ensemble members. For the short term, estimates vary between $0.01 \mathrm{t} / \mathrm{ha}$ and $0.3 \mathrm{t} / \mathrm{ha}$. For the mid-term it varies between $0.01 \mathrm{t} / \mathrm{ha}$ and $0.14 \mathrm{t} / \mathrm{ha}$ and, finally, for the long-term estimates vary from $0.05 \mathrm{t} / \mathrm{ha}$ to $0.17 \mathrm{t} / \mathrm{ha}$. Standard deviations show that the greatest variation between the members exists in the shortterm projections. Models varied between 3\% and 30\%; the biggest variation was in the long-term estimates and the smallest was in the short-term estimates. From Fig. 3, variation in rainfall between the models was $5 \%$ whereas sediment yield here varies from $3-30 \%$. This shows how the feedback between rainfall and sediment yield is non-linear.
Table 3. The sediment yield projected by each ensemble member for each time period

\begin{tabular}{lccc}
\hline Ensemble member & \multicolumn{3}{c}{ Sediment yield (t/ha) } \\
\cline { 2 - 4 } & $\mathbf{2 0 1 5 - 2 0 3 5}$ & $\mathbf{2 0 4 0 - 2 0 6 5}$ & $\mathbf{2 0 8 1 - 2 1 0 0}$ \\
\hline CSIRO & 0.05 & 0.02 & 0.17 \\
GFDLv & 0.05 & 0.03 & 0.15 \\
GFDL 2 & 0.07 & 0.06 & 0.05 \\
MIROC & 0.01 & 0.01 & 0.01 \\
MPI & 0.03 & 0.03 & 0.07 \\
UKMO & 0.3 & 0.14 & 0.12 \\
Mean & 0.08 & 0.05 & 0.1 \\
Standard deviation & 0.11 & 0.05 & 0.06 \\
\hline
\end{tabular}




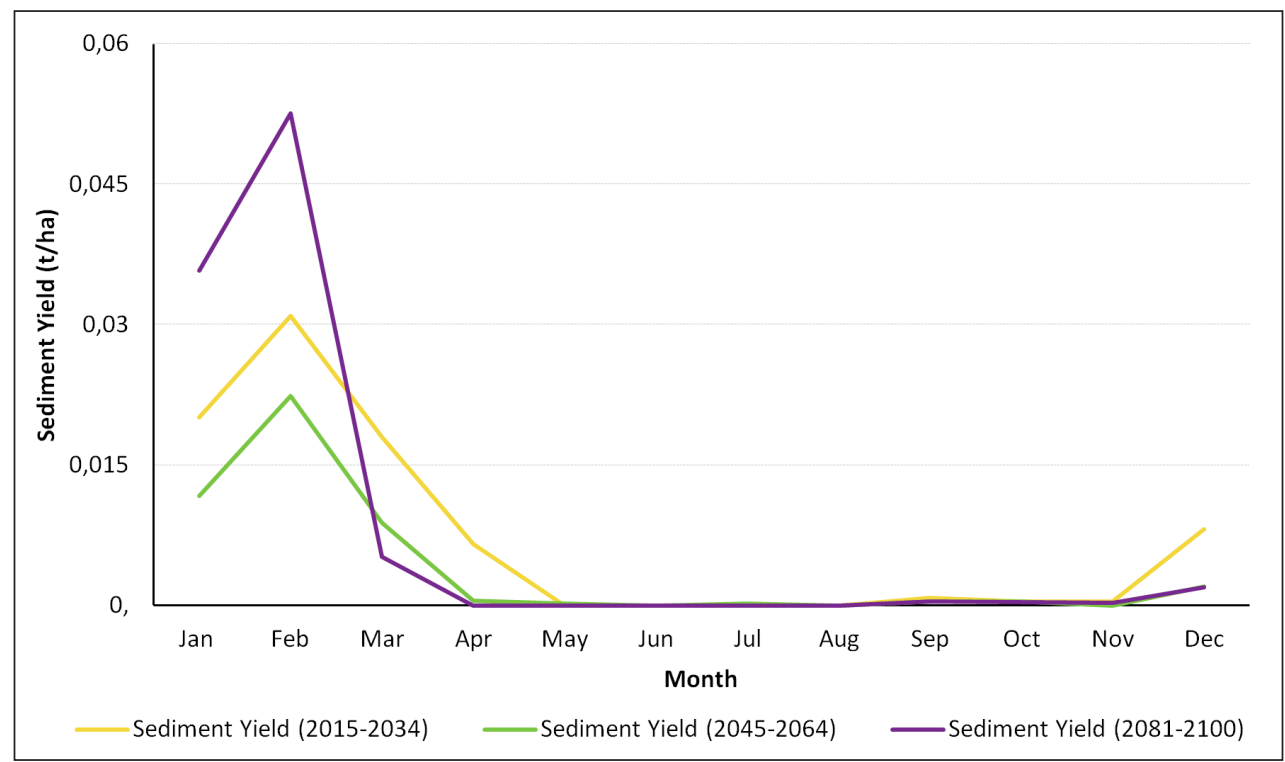

Figure 8. The average monthly sediment yield modelled in SWAT from the average of the six CGCM models for the periods 2015-2035, 2045-2064, 2081-2100

Figure 8 shows that sediment yield contribution is highest in the summer rainfall months. This is expected as the catchment falls in a summer rainfall region. The peak sediment contribution will likely remain in February; however, the peak sediment yield will likely increase more than 2 -fold from $0.02 \mathrm{t} / \mathrm{ha}$ in $2045-2064$ to $0.05 \mathrm{t} /$ ha in $2081-2100$.

\section{DISCUSSION}

The study sought to provide a preliminary investigation into the effects of climate change on soil loss by sheet and rill erosion in a South African catchment earmarked for a potential water resource development. Results show that the effects of climate change in the upper Tsitsa catchment will likely lead to an increase (up to $14 \%$ ) in rainfall erosivity and sediment yield up to 2100 . This is most likely due to a projected increase in larger rainfall events (>10 mm), which is consistent with documented findings within South Africa (Engelbrecht et al., 2013). Rainfall intensity is a major contributor to the erosivity factor and sediment yield. Higher rainfall intensities have been shown to result in greater runoff (Mohamadi and Kavian, 2015). Similar soil losses were detailed in the study by Simonneaux et al. (2015), who found that climate change would lead to an increase in sediment yield by $4.7-10.1 \%$. Peak sediment yield will occur as at present in the summer months but is likely to increase more than two-fold in the long term.

Since the catchment is dominated by gully erosion, siltation of the dam will be affected more by the erosion rates of gullies. Although this study did not assess climate change effects on gully erosion, its effects on sheet and rill erosion may be an indicator for increased gully erosion under climate change.

By creating three separate time periods, our results can be useful to understand the projected climate prevailing in the various life stages of the dam. The likelihood of high sedimentation projected in the short-term (2015-2034) may coincide with the planning, building and initial management of the reservoir. These potential impacts can, thus, be included in the design of dam infrastructure as well as land management scenarios which will lower erosion rates from the onset. The lower erosion rates projected in the mid-term, which then increase in the longer term, highlight the importance of ongoing and flexible siltation management to optimise the dam's lifespan over the century. This may be partially explained by the lower range in rainfall during the 2045-2064 period, but more studies should be conducted using newer climate models, different downscalings (dynamical vs statistical), and/or more grid points, to establish whether this observation is part of a long-term trend.

Model uncertainty was partly overcome in this study by using all six available ensemble members. This gave an advantage over the use of a single model in terms of being able to quantify uncertainty in projections and resulted in a range of possible estimates (Crosbie et al., 2012). It is important here to acknowledge the underestimation of rainfall by the CGCMs, in particular extreme rainfall events which will have the greatest effect on the sediment yield results. Although CGCMs can reliably and skilfully project changes in temperature, they are less skilled in predicting changes in rainfall at the local scale (Schulze et al., 2011). Since soil erosion is largely controlled by rainfall, and heavy thunderstorms result in greater runoff than do lighter rainfall events, the CGCMs likely cause an underestimation of sediment yield by SWAT. As such, several advances need to be made to improve soil erosion monitoring and modelling with regards to future climate. These include better representation of extreme events in climate models and the integration of, and distinction between, the various soil erosion processes such as rill, gully, or channel erosion in hydrological/sediment yield models. Because of these limitations, it is highly recommended that uncertainty be regularly included as part of the risk in decision making when it comes to water resource management for southern Africa (Kusangaya et al., 2014).

It should be noted that the focus of this study was to gauge relative changes in soil loss up to 2100. According to Mullan et al. (2012), there are numerous benefits of using relative soil loss rates. First, even if SWAT fails to accurately simulate the absolute soil loss rates from projected climate change data, it will still be able to simulate relative changes. Second, and most importantly, since the results from calculating relative changes are influenced only by the altered parameters, in this case the weather (rainfall, minimum and maximum temperature) inputs, they are better able to isolate the impacts and contribution of climate change to the future erosion problem (Mullan et al., 2012).

Dam design can have a considerable effect on the lifespan of the dam. Dam construction considerations may include the building of sediment traps or settling facilities or the construction of an underwater dike or massive tunnels which allow for annual sluicing (Ferreira and Waygood 2009). However, preventing upstream soil erosion has substantial advantages for a dam's lifespan, as well as 
social and economic benefits which can improve overall resilience of the catchment in the long term (Plamieri et al., 2001). Changing land management practices in response to climate change and other external factors will likely also affect sediment yield (Routschek et al., 2014; Simonneaux et al., 2015). It is recommended that better land management practices which lessen erosion be introduced; these include rotational grazing, limiting stock sizes to the carrying capacity of the land and the use of conservation farming techniques (Hendershot, 2004; Gruver, 2013). Land use and land management were not considered in this study because their inclusion in the model would have created the need for further assumptions and added additional uncertainty, since the likely response of land management to climate change is unknown.

\section{CONCLUSION}

It is widely accepted that climate change will bring about large changes in the hydrological cycle, most likely causing increased frequency and intensity of extreme rainfall events (Nearing et al., 2004; Seneviratne et al., 2012; Tabari, 2020). Numerous studies have shown that extreme rainfall events lead to increased runoff and sedimentation of reservoirs (Msadala et al., 2010; Mullan, 2013; Pretorius 2017). However, few studies have focused on the effects of climate change on sediment yield and erosivity, most notably in Africa (Nearing et al., 2004; Mullan et al., 2012; Simonneaux et al., 2015). Adequate water resource development is an integral part of economic growth and will play a vital role in climate change resilience in the warmer, drier regions of subSaharan Africa (Wu et al., 2009).

This study highlighted the potential effects of changing climate on a rural, sub-humid, South African catchment earmarked for a major water resource development. Our results show that climate change will likely lead to increased sedimentation in the catchment, particularly in the long term. Peak sediment yield will also increase almost three-fold throughout the century, most likely caused by an increase in larger rainfall events. The study emphasised the need for changes in climate to be considered when embarking on water resource developments. It is hoped that these results will inform decision makers, as well as open the discourse for further research on the impacts of climate change on water resources, particularly sedimentation, in this catchment as well as others in sub-Saharan Africa.

\section{ACKNOWLEDGEMENTS}

The authors would like to thank the Agricultural Research Council for the funding and research support provided for this study. Research for this publication formed part of the MSc dissertation completed by Ms SN Theron (formerly Pretorius) (2017) at the University of Pretoria and can be found at https:// repository.up.ac.za/handle/2263/60852.

\section{CONFLICT OF INTEREST STATEMENT}

The authors certify that they have no affiliations with or involvement in any organisation or entity with any financial interest or non-financial interest in the subject matter or materials discussed in this manuscript.

\section{ORCID}

SN Theron

https://orcid.org/0000-0002-8895-9464

\section{REFERENCES}

AGRO-METEOROLOGY STAFF (1984-2020) Agro-meteorology weather station network data for South Africa. Agricultural Research Council Institute for Soil Climate and Water, Pretoria.
ALEMAW BF, MAJAUALE M and SIMALENGA T (2013) Assessment of sedimentation impacts on small dams- A case of small reservoirs in the Lotsane catchment. J. Water Resour. Protect. 5 (12) 1127-1132. https://doi.org/10.4236/jwarp.2013.512118.

ARNOLD JG, KINIRY JR, SRINIVASAN R, WILLIAMS EB, HANEY EB and NEITSCH SL (2012) SWAT: input/output file documentation, version 2012, report no. TR-439. Texas Water Resources Institute: Texas USA URL: https://swat.tamu.edu/media/69296/swat-io-docu mentation-2012.pdf (Accessed 12 July 2018).

BOURAOUI F, BENABDALLAH S, JRAD A and BIDOGLIO G (2005) Application of the SWAT model on the Medjerda river basin (Tunisia). Phys. Chem. Earth A/B/C. 30 (8-10) 497-507. https://doi. org/10.1016/j.pce.2005.07.004.

COSTEA M (2012) Using the Fournier indexes in estimating rainfall erosivity. Case study-the Secasul Mare Basin. Air Water Components Environ. 2012 313-320.

ENGELBRECHT FA, LANDMAN WA, ENGELBRECHT CJ, LANDMAN S, BOPAPE MM, ROUX B, MCGREGOR JL and THATCHER M (2011) Multi-scale climate modelling over Southern Africa using a variable-resolution global model. Water SA. 37 (5) 647-658. https://doi.org/10.4314/wsa.v37i5.2.

ENGELBRECHT CJ, ENGELBRECHT FA and DYSON LL (2013) High-resolution model-projected changes in mid-tropospheric closed-lows and extreme rainfall events over southern Africa. Int. J. Climatol. 33 (1) 173-187. https://doi.org/10.1002/joc.3420.

ENGELBRECHT CJ and ENGELBRECHT FA (2016) Shifts in KöppenGeiger climate zones over southern Africa in relation to key global temperature goals. Theor. Appl. Climatol. 123 (1-2) 247-261. https:// doi.org/10.1007/s00704-014-1354-1.

DAVIS-REDDY CL, VINCENT K and MAMBO J (2017) Socioeconomic impacts of extreme weather events in Southern Africa. Council for Scientific and Industrial Research, Pretoria.

DEA (Department of Environmental Affairs, South Africa) (2013) LongTerm Adaptation Scenarios (LTAS) Flagship Research Programme for South Africa - Climate change implications for the water sector in South Africa. South African National Bio-diversity Institute and Department of Environmental Affairs, Pretoria.

DEA (Department of Environmental Affairs, South Africa) (2015) DEA National Landcover (TIFF). Biodiversity GIS. DEA, Pretoria.

DEA (Department of Environmental Affairs, South Africa) (2016) South African National Adaptation Strategy. DEA, Pretoria.

DWS (Department of Water and Sanitation, South Africa) (2014) Environmental Impact Assessment for the Mzimvubu: Environmental Impact Assessment Report. DWS, Pretoria.

DWS (Department of Water and Sanitation, South Africa) (N.d) Strategic plan for the fiscal years 2020/2021 to 2024/25. DWS, Pretoria.

FERREIRA S and WAYGOOD C (2009) A South African case study on sediment control measures with the use of silt traps in the coal mining industry. In: Abstracts of the International Mine Water Conference, 19-23 October 2009, Pretoria.

FLÖRKE M, SCHNEIDER C and MCDONALD RI (2018) Water competition between cities and agriculture driven by climate change and urban growth. Nat. Sustainability. 1 (1) 51-58. https:// doi.org/10.1038/s41893-017-0006-8.

GODWIN MA, GABRIEL S, HODSON M and WELLINGTON D (2011) Sedimentation impacts on reservoir as a result of land use on a selected catchment in Zimbabwe. Int. J. Eng. Sci. Technol. 3 (8) 6599-6608.

GRUVER JB (2013) Prediction, prevention and remediation of soil degradation by water erosion. Nat. Educ. Knowl. 4 (12) URL: https://www.nature.com/scitable/knowledge/library/predictionprevention-and-remediation-of-soil-degradation-113130829/ (Accessed 20 October 2020).

HEDDEN S and CILLIERS J (2014) Parched prospects: the emerging water crisis in South Africa. African Futures Paper No. 11. Institute for Security Studies. https://doi.org/10.2139/ssrn.2690124.

HENDERSHOT R (2004) Environmental benefits of improved grazing management. Pasture. http://livestocktrail.illinois.edu/pasturenet/ paperDisplay.cfm?ContentID=6618 (Accessed 20 October 2020).

KUSANGAYA S, WARBURTON ML, VAN GARDEREN EA and JEWITT GP (2014) Impacts of climate change on water resources in southern Africa: A review. Phys. Chem. Earth A/B/C. 67 47-54. https://doi.org/10.1016/j.pce.2013.09.014. 
LAND TYPE SURVEY STAFF (1972-2006) Land Types of South Africa: Digital map (1:250 000 scale) and soil inventory databases. ARCInstitute for Soil, Climate and Water, Pretoria.

LE ROUX JJ, BARKER CH, WEEPENER HL, VAN DEN BERG EC and PRETORIUS SN (2015) Sediment Yield Modelling in the Mzimvubu River Catchment. WRC Report No. 2243/1/15. Water Research Commission, Pretoria.

LE ROUX JJ, SUMNER PD, LORENTZ SA and GERMISHUYSE T (2013) Connectivity aspects in sediment migration modelling using the Soil and Water Assessment Tool. Geosciences. 3 (1) 1-12.

LE ROUX JJ (2018) Sediment yield potential in South Africa's only large river network without a dam: Implications for water resource management. Land Degrad. Dev. 29 (3) 765-775. https://doi.org/ 10.1002/ldr. 2753

MAMA CN and OKAFOR FO (2011) Siltation in reservoirs. Nig. J. Technol. 30 (1) 85-90.

MANASE G (2010) Impact of climate change on water in southern africa: research on climate change and water resources in Southern Africa. Council for Scientific and Industrial Research and Danish Water Forum.

MALHERBE J, ENGELBRECHT FA and LANDMAN WA (2013) Projected changes in tropical cyclone climatology and landfall in the southwest Indian Ocean region under enhanced anthropogenic forcing. Clim. Dyn. 40 (11-12) 2867-2886. https://doi.org/10.1007/ s00382-012-1635-2

MARTINEC J and RANGO A (1989) Merits of statistical criteria for the performance of hydrological models. J. Am. Water Resour. Ass. 25 (2) 421-432. https://doi.org/10.1111/j.1752-1688.1989.tb03079.x

MSADALA V, GIBSON L, LE ROUX J, ROOSEBOOM A and BASSON GR (2010) Sediment yield prediction for South Africa: 2010 Edition. WRC Report No. 1765/1/10. Water Research Commission, Pretoria.

MULLAN D, FAVIS-MORTLOCK D and FEALY R (2012) Addressing key limitations associated with modelling soil erosion under the impacts of future climate change. Agric. For. Meteorol. 156 18-30 https://doi.org/10.1016/j.agrformet.2011.12.004

MULLAN D (2013) Soil erosion under the impacts of future climate change: Assessing the statistical significance of future changes and the potential on-site and off-site problems. Catena. 109 234-246. https://doi.org/10.1016/j.catena.2013.03.007

NAKICENOVIC NJ, ALCAMO J, DAVIS G, VRIES B, FENHANN J, GAFFIN S, GREGORY K, GRUBLER A, JUNG TY, KRAM T and co-authors (2000) IPCC Special Report on Emissions Scenarios. Cambridge University Press, Cambridge.

NASH JE and SUTCLIFFE JV (1970) River flow forecasting through conceptual models part I- A discussion of principles. J. Hydrol. 10 (3) 282-290. https://doi.org/10.1016/0022-1694(70)90255-6

NDOMBA PM and VAN GRIENSVEN A (2011) Suitability of SWAT Model for sediment yields modelling in the Eastern Africa, advances in data, methods, models and their applications in geoscience. Technical Paper, University of Dares Salam.

NEARING MA, PRUSKI FF and O'NEAL MR (2004) Expected climate change impacts on soil erosion rates: a review. J. Soil Water Conserv. 59 (1) 43-50.

NIANG I, RUPPEL OC, ABDRABO MA, ESSEL A, LENNARD C, PADGHAM J and URQUHART P (2014) Africa. Climate change 2014 Impacts, adaptation, and vulnerability. Part B: Regional aspects. In: Contribution of Working Group II to the Fifth Assessment Report of the Intergovernmental Panel on Climate Change. Cambridge University Press, Cambridge, United Kingdom and New York. 1199-1265.

OTTO FE, WOLSKI P, LEHNER F, TEBALDI C, VAN OLDENBORGH GJ, HOGESTEEGER S, SINGH R, HOLDEN P, FUČKAR NS, ODOULAMI RC and NEW M (2018) Anthropogenic influence on the drivers of the Western Cape drought 2015-2017. Environ. Res. Lett. 13 (12) 124010. https://doi.org/10.1088/1748-9326/aae9f9

PLAMIERI A, SHAH F and DINAR A (2001) Economics of reservoir sedimentation and sustainable management of dams. J. Environ. Manage. 61 149-163. https://doi.org/10.1006/jema.2000.0392

PRETORIUS SN (2017) Sediment yield modelling in the upper Tsitsa Catchment, Eastern Cape, South Africa. MSc dissertation, University of Pretoria.
RAWLINS J (2019) Political economy of water reallocation in South Africa: Insights from the Western Cape water crisis. Water Security. 6 100029. https://doi.org/10.1016/j.wasec.2019.100029

SAUERBORN P, KLEIN A, BOTSCHEK J and SKOWRONEK A (1999) Future rainfall erosivity derived from large-scale climate modelsmethods and scenarios for a humid region. Geoderma. 93 (3-4) 269-276. https://doi.org/10.1016/S0016-7061(99)00068-3

SCHELLENBERG G, DONNELL R, HOLDER C and AHSAN R (2017) Dealing with sediment: effects on dams and hydropower generation. Hydro Rev. 1 (25).

SCHULZE RE, HEWITSON BC, BARICHIEVY KR, TADROSS M, KUNZ RP and HORAN MJC (2011) Methodological approaches to assessing eco-hydrological responses to climate change in South Africa. WRC Report No. 1562/1/10 Water Research Commission, Pretoria.

SENEVIRATNE SI, NICHOLLS N, EASTERLING D, GOODESS CM, KANAE S, KOSSIN J, LUO Y, MARENGO J, MCINNES K, RAHIMI M and co-authors (2012) Changes in climate extremes and their impacts on the natural physical environment. In Managing the Risks of Extreme Events and Disasters to Advance Climate Change Adaptation: A Special Report of Working Groups I and II of the Intergovernmental Panel on Climate Change. Cambridge University Press, Cambridge and New York. 109-230.

SETEGN SG, RAYNER D, MELESSE AM, DARGAHI B and SRINIVASAN R (2011) Impact of climate change on the hydroclimatology of Lake Tana Basin Ethiopia. Water Resour. Res. 47 (4). https://doi.org/10.1029/2010WR009248

SIMONNEAUX V, CHEGGOUR A, DESCHAMPS C, MOUILLOT F, CERDAN O and LE BISSONNAIS Y (2015) Land use and climate change effects on soil erosion in a semi-arid mountainous watershed (High Atlas Morocco). J. Arid Environ. 122 64-75. https://doi. org/10.1016/j.jaridenv.2015.06.002

SIWI (Stockholm International Water Institute) (2005) Making water a part of economic development. Governments of Norway and Sweden. SIWI, Stockholm.

TABARI H (2020) Climate change impact on flood and extreme precipitation increases with water availability. Sci. Rep. 1013768. https://doi.org/10.1038/s41598-020-70816-2

TIBEBE D and BEWKET W (2011) Surface runoff and soil erosion estimation using the SWAT model in the Keleta watershed Ethiopia. Land Degrad. Dev. 22 (6) 551-564. https://doi.org/10.1002/ldr.1034

VAN GRIENSVEN AV, NDOMBA P, YALEW S and KILONZO F (2012) Critical review of SWAT applications in the upper Nile basin countries. Hydrol. Earth Syst. Sci. 16 (9) 3371-3381. https://doi. org/10.5194/hess-16-3371-2012.

VAN TOL J, AKPAN W, KANUKA G, NGESI S and LANGE D (2014) Soil erosion and dam dividends: science facts and rural 'fiction' around the Ntabelanga dam Eastern Cape South Africa. S. Afr. Geogr. J. 98 (1) 169-181. https://doi.org/10.1080/03736245.2014.977814

VAN VUUREN DP, EDMONDS J, KAINUMA M, RIAHI K, THOMSON A, HIBBARD K, HURTT GC, KRAM T, KREY V, LAMARQUE JF and MASUI T (2011) The representative concentration pathways: an overview. Clim. Change. 109 (1-2) 5. https:// doi.org/10.1007/s10584-011-0148-z

WAHREN FT, JULICH S, NUNES JP, GONZALEZ-PELAYO O, HAWTREE D, FEGER KH and KEIZER JJ (2016) Combining digital soil mapping and hydrological modelling in a data scarce watershed in north-central Portugal. Geoderma. 264 350-362. https://doi. org/10.1016/j.geoderma.2015.08.023

WEEPENER HL, VAN DEN BERG HM, METZ $M$ and HAMANDAWANA H (2012) The development of a hydrologically improved digital elevation model and derived products for South Africa based on the SRTM DEM. WRC Report No.1908/1/11. Water Research Commission, Pretoria.

WU S, BATES B, ZBIGNIEW KUNDZEWICZ AW and PALUTIKOF J (2009) Climate change and water. Technical Paper of the Intergovernmental Panel on Climate Change. IPCC, Geneva.

YAHAYA AS, AHMAD F, MOHTAR ZA and SURI S (2016) Determination of rainfall erosivity in Penang. Jap. Geotech. Soc. Special Publication. 2 (31) 1132-1136. https://doi.org/10.3208/jgssp. ATC1-3-05 